\title{
Effect of Bleaching on Sound Enamel and with Early Artificial Caries Lesions Using Confocal Laser Microscopy
}

\author{
Sandrine Bittencourt BERGER ${ }^{1}$ \\ Sabrina PAVAN ${ }^{2}$ \\ Paulo Henrique DOS SANTOS ${ }^{3}$ \\ Marcelo GIANNINI ${ }^{4}$ \\ Ana Karina B. BEDRAN-RUSSO ${ }^{2}$
}

\author{
${ }^{1}$ Department of Restorative Dentistry, UNOPAR - University of North Paraná, Londrina, PR, Brazil \\ ${ }^{2}$ Department of Restorative Dentistry, Dental School, University of Illinois at Chicago, Chicago, IL, USA \\ ${ }^{3}$ Department of Dental Materials and Prosthodontics, Araçatuba Dental School, \\ UNESP - Univ Estadual Paulista, Araçatuba, SP, Brazil \\ ${ }^{4}$ Department of Restorative Dentistry, Piracicaba Dental School, UNICAMP - University of Campinas, \\ Piracicaba, SP, Brazil
}

\begin{abstract}
The aim of this study was to evaluate effect of bleaching agents on sound enamel (SE) and enamel with early artificial caries lesions (CL) using confocal laser scanning microscopy (CLSM). Eighty blocks (4 x 5 x $5 \mathrm{~mm}$ ) of bovine enamel were used and half of them were submitted to a $\mathrm{pH}$ cycling model to induce CL. Eight experimental groups were obtained from the treatments and mineralization level of the enamel (SE or CL) (n=10). SE groups: G1 - unbleached (control); G2 - 4\% hydrogen peroxide (4 HP); G3 - 4 HP containing $0.05 \% \mathrm{Ca}(\mathrm{Ca})$; $\mathrm{G} 4-7.5 \%$ hydrogen peroxide (7.5 HP) containing amorphous calcium phosphate (ACP). CL groups: G5 - unbleached; G6 - 4 HP; G7 - 4 HP containing Ca; G8 - 7.5 HP ACP. G2, G3, G6, G7 were treated with the bleaching agents for 8 h/day during 14 days, while G4 and G8 were exposed to the bleaching agents for 30 min twice a day during 14 days. The enamel blocks were stained with $0.1 \mathrm{mM}$ rhodamine B solution and the demineralization was quantified using fluorescence intensity detected by CLSM. Data were analyzed using ANOVA and Fisher's tests $(\alpha=0.05)$. For the SE groups, the bleaching treatments increased significantly the demineralization area when compared with the unbleached group. In the CL groups, no statistically significant difference was observed ( $>0.05$ ). The addition of ACP or Ca in the composition of the whitening products did not overcome the effects caused by bleaching treatments on SE and neither was able to promote remineralization of CL.
\end{abstract}

Key Words: Bovine enamel, whitening, confocal laser scanning microscopy.

\section{INTRODUCTION}

Vital tooth bleaching has gained popularity in recent years as an easy, affordable, and conservative way of treating discolored teeth. Since its introduction, bleaching has been accepted as an efficient and simple aesthetic procedure for removing intrinsic and extrinsic stains from teeth $(1,2)$. In the last decade, many products with varying concentrations and techniques have been indicated for in-office use or mouthguard bleaching (3).

Bleaching occurs due to the decomposition of peroxide into free radicals, which subsequently react with the large pigment molecules, transforming them into smaller, less pigment molecules and so the hydrogen peroxide (HP) oxidizes a wide variety of organic compounds $(1,2)$. Some studies have found mineral loss, increased susceptibility to erosion or caries, increased surface roughness, reduced enamel tensile strength, reduced fracture stability or a decrease in abrasion resistance of bleached dental hard tissues $(4,5)$.

In an attempt to decrease tooth sensitivity, reestablish surface hardness and support remineralization of initial white spot lesions, some manufacturers have incorporated fluorides into their bleaching gel 
formulations $(6,7)$. More recently, amorphous calcium phosphate (ACP) has become available in tooth whitening products; however, the effects of ACP on enamel remineralization have rarely been analyzed (8). Calcium $(\mathrm{Ca})$ ions have also been added in the bleaching agent's composition, however, little is known about the effectiveness of the ACP's components (9).

This study used confocal laser scanning microscopy (CLSM) to evaluate the effect of bleaching agents containing $\mathrm{Ca}$ on sound enamel and with early artificial caries lesions. The null hypothesis was that the Ca-containing bleaching agents would not effect the demineralization of sound enamel and promote remineralization of early artificial caries lesions.

\section{MATERIAL AND METHODS}

\section{Specimen Preparation}

Twenty extracted sound bovine incisors stored in $0.1 \%$ thymol solution were used within 1 month of extraction. The roots were separated from the crowns with a water cooled low-speed diamond saw (BuehlerSeries 15LC Diamond; Buehler, Lake Bluff, IL, USA). Crowns were sectioned mesio-distally and buccal- lingually to obtain 4 dental blocks ( $4 \mathrm{~mm}$ long x $3 \mathrm{~mm}$ wide $\mathrm{x} 3 \mathrm{~mm}$ thick) from each crown. Except for the buccal surfaces, all other surfaces of the dental blocks were sealed with acid-resistant nail polish (Revlon Corp., New York, NY, USA). Eighty dental blocks were randomly assigned to 8 groups $(\mathrm{n}=10)$.

\section{Induction of Early Artificial Caries Lesions ( $\mathrm{pH}$ Cycling) and Bleaching}

Forty samples were subjected to a $\mathrm{pH}$ cycling model to induce early artificial carious lesions, while other 40 enamel samples remained sound. All dental blocks were submitted to a 8-day $\mathrm{pH}$-cycling regimen, simulating daily acid challenge and bleaching treatments. Each cycle consisted of an individual immersion in a demineralization solution $\left(3.12 \mathrm{~mL} / \mathrm{mm}^{2}\right.$; composition: $1.4 \mathrm{mMCa}, 0.9 \mathrm{mM} \mathrm{P}, 0.05 \mathrm{M}$ acetate buffer, $\mathrm{pH}$ 5.0) and remineralization solution $\left(1.56 \mathrm{~mL} / \mathrm{mm}^{2}\right.$; composition: $1.5 \mathrm{mM} \mathrm{Ca}, 0.9 \mathrm{mM}$ P, $0.1 \mathrm{M}$ Tris buffer, $\mathrm{pH}$ 7.0) for 8 and $16 \mathrm{~h}$, respectively. Between immersions, and at the end of the cycle, the samples were rinsed with distilled and deionized water and gently dried with absorbent paper (10). Immediately after $\mathrm{pH}$ cycling, samples were subject to bleaching treatments described in Table 1 .

Table 1. Material used in the study.

\begin{tabular}{|c|c|c|c|c|c|c|}
\hline Group & Enamel & $\begin{array}{l}\text { Bleaching } \\
\text { agent }\end{array}$ & Concentration & $\begin{array}{l}\text { Application } \\
\text { time }\end{array}$ & $\begin{array}{l}\text { Treatment } \\
\text { duration }\end{array}$ & Manufacturer \\
\hline 1 (control) & Sound & Unbleached & & & & \\
\hline 2 & Sound & $\begin{array}{l}\text { Experimental } \\
\text { bleaching }\end{array}$ & $4 \% \mathrm{HP}+0.05 \% \mathrm{Ca}$ & 8 h daily & 14 days & $\begin{array}{l}\text { FGM Prod. Odont., } \\
\text { Joinville, SC, Brazil }\end{array}$ \\
\hline 3 & Sound & $\begin{array}{l}\text { Experimental } \\
\text { bleaching }\end{array}$ & $4 \% \mathrm{HP}$ & 8 h daily & 14 days & $\begin{array}{l}\text { FGM Prod. Odont., } \\
\text { Joinville, SC, Brazil }\end{array}$ \\
\hline 4 & Sound & DayWhite ACP & $7.5 \% \mathrm{HP}+\mathrm{ACP}$ & $\begin{array}{l}30 \text { min - } \\
\text { Twice daily }\end{array}$ & 14 days & $\begin{array}{c}\text { Discus Dental, Culver } \\
\text { City, CA, USA. }\end{array}$ \\
\hline 5 (control) & w/ EACL & Unbleached & & & & \\
\hline 6 & w/ EACL & $\begin{array}{l}\text { Experimental } \\
\text { bleaching }\end{array}$ & $\begin{array}{l}4 \% \mathrm{HP}+ \\
0.05 \% \mathrm{Ca}\end{array}$ & 8 h daily & 14 days & $\begin{array}{l}\text { FGM Prod. Odont., } \\
\text { Joinville, SC, Brazil }\end{array}$ \\
\hline 7 & w/ EACL & $\begin{array}{l}\text { Experimental } \\
\text { bleaching }\end{array}$ & $4 \% \mathrm{HP}$ & 8 h daily & 14 days & $\begin{array}{l}\text { FGM Prod. Odont., } \\
\text { Joinville, SC, Brazil }\end{array}$ \\
\hline 8 & w/ EACL & DayWhite ACP & $7.5 \% \mathrm{HP}+\mathrm{ACP}$ & $\begin{array}{c}30 \mathrm{~min}- \\
\text { Twice daily }\end{array}$ & 14 days & $\begin{array}{c}\text { Discus Dental, Culver } \\
\text { City, CA, USA. }\end{array}$ \\
\hline
\end{tabular}

EACL: early artificial caries lesions; HP: hydrogen peroxide; ACP: amorphous calcium phosphate. 
The enamel blocks were daily exposed to bleaching agent with $0.05 \mathrm{~mL}$ of artificial saliva and covered with an individual tray (10).

\section{Post-Treatment Analysis}

Samples were sectioned longitudinally through the treated area with a low speed water-cooled diamond saw (Isomet 1000; Buehler) and embedded perpendicular to the demineralized surface in epoxy resin (Buehler). Next, the samples were polished on a water-cooled polishing unit (EcoMet 3000; Buehler) with abrasive paper (400-, 600- and 1200-grit) and 0.3 and $0.1 \mu \mathrm{m}$ diamond mask alumina suspension (Metaldi Supreme; Buehler). The polished samples were cleaned ultrasonically in deionized water for $15 \mathrm{~min}$ to remove the residues from polishing procedure.

\section{CLSM}

The samples were immersed in a fresh $0.1 \mathrm{mM}$ rhodamine B solution (Aldrich Chem. Co., Milwaukee, WI, USA) for $1 \mathrm{~h}$, without further water-rinsing $(11,12)$. Samples were analyzed with CLSM (Zeiss LSM 510; Carl Zeiss, Inc., Germany), using an argon laser with a 529-nm excitation wavelength. Areas were scanned between 10 and $50 \mu \mathrm{m}$ below the treated surface to reduce the influence of the smear layer created during the cutting and polishing procedure $(11,12)$. The quantification of fluorescence demineralization area was analyzed with an image-analysis system (ImageJ 1.41; Wayne Rasband, National of Institutes of Health, Bethesda, MD, USA).

\section{Statistical Analysis}

Data were analyzed statistically by two-way ANOVA (factors: bleaching treatments $\mathrm{x}$ enamel conditions) at a $95 \%$ confidence interval and Fisher's PLSD test.

\section{RESULTS}

The total fluorescence demineralization area (in $\mu \mathrm{m}^{2}$ ) and standard deviations (S.D.) are shown in Table 2. Two-way ANOVA revealed that there was statistically significant difference for both factors "enamel" $(p<0.0001)$ and "bleaching treatment" $(p=0.0189)$. However, the interaction between these factors was not statistically significant $(\mathrm{p}=0.1510)$.
Fisher's PLSD test showed that sound enamel presented increase of demineralization area after bleaching treatments when compared to a control group $(p \leq 0.0004)$. The fluorescence area in sound enamel for each bleaching treatment is depicted in Figure 1. The results of fluorescence area (demineralization) in the groups with early artificial caries lesions showed no significant difference among bleaching treatments $(p=0.4795)$. The bleached groups were also statistically similar to the control group ( $p>0.05)$. Figure 2 illustrates the fluorescence areas of the groups with early artificial caries lesions. Comparison between the enamel condition (sound versus early artificial caries lesions) showed statistically significant difference $(\mathrm{p}<0.0207)$.

\section{DISCUSSION}

The first use of CLSM in dental research was proposed by Watson in 1989 (13). The objective of that study was to evaluate the morphology of the tooth-composite interfaces. González-Cabezas et al. (11) reported that CLSM could be used with thin enamel sections or half a tooth stained with a $0.1 \mathrm{mM}$ solution of Rhodamine B. This method can replace or supplement microradiography analysis that quantify the demineralization and analyze the remineralization phenomenon. Few studies have used CSLM to evaluate the effect of bleaching agents on tooth structure $(14,15)$, therefore, this study compared the effect of different formulations of bleaching agents on enamel demineralization of sound enamel and with early artificial caries lesions by quantifying the fluorescence areas.

Table 2. Total area of demineralization (in $\mu \mathrm{m}^{2}$ ) and standard deviation in the groups measured by fluorescent dye using confocal laser scanning microscopy.

\begin{tabular}{lcc}
\hline Treatments & Sound enamel & Enamel w/ EACL \\
\hline Unbleached & $4.8(2.2)^{\mathrm{B}, \mathrm{a}}$ & $19.6(7.6)^{\mathrm{A}, \mathrm{b}}$ \\
$4 \% \mathrm{HP}+0.05 \% \mathrm{Ca}$ & $10.8(4.0)^{\mathrm{A}, \mathrm{a}}$ & $20.3(9.0)^{\mathrm{A}, \mathrm{b}}$ \\
$4 \% \mathrm{HP}$ & $11.4(3.6)^{\mathrm{A}, \mathrm{a}}$ & $20.9(6.6)^{\mathrm{A}, \mathrm{b}}$ \\
$7.5 \% \mathrm{HP}+\mathrm{ACP}$ & $10.9(4.2)^{\mathrm{A}, \mathrm{a}}$ & $18.6(5.0)^{\mathrm{A}, \mathrm{b}}$ \\
\hline
\end{tabular}

Different uppercase letters in columns and lowercase letters in rows indicate statistically significant differences among groups (Fisher's test, $\mathrm{p}<0.05$ ). HP: hydrogen peroxide; ACP : amorphous calcium phosphate; EACL: early artificial caries lesions. 
The bleaching products tested in this study contained as active ingredient the $4 \%$ and $7.5 \% \mathrm{HP}$ and were applied for $8 \mathrm{~h}$ daily or for $30 \mathrm{~min}$ twice daily, respectively. One was a commercial product (with $\mathrm{ACP}$ ) and the other two were experimental bleaching agents that contained only $7.5 \% \mathrm{HP}$ or the addition of $0.05 \% \mathrm{Ca}$. All bleached groups were compared with unbleached groups and the results of this in vitro study demonstrated that a 14-day regimen of whitening using different formulations of bleaching agents produced different results on sound enamel and enamel with early artificial caries lesion. Sound enamel was more resistant to demineralization than carious enamel, which showed larger fluorescence demineralization area.

Moreover, the bleached groups showed similar demineralization fluorescence areas to unbleached groups, regardless of enamel conditions. Thus, the null hypothesis of this study was accept, since that the addition of $\mathrm{Ca}$ or ACP did not reduce the demineralization area on sound enamel and did not promote remineralization of the enamel with early artificial lesions. Tschoppe et al. (6) also evaluated the effect of fluoridated and ACP containing bleaching gels on remineralization of predemineralized bovine enamel and did not observed mineral uptake, which support the results of the present study.

A previous study evaluated some commercial bleaching agents containing HP or carbamide peroxide (CP) and did not found alterations on surface morphology after bleaching (4). However, other studies reported that bleaching agents produced mineral loss and formation of porosities on enamel surface $(3,16-18)$. The surface and subsurface changes correspond to the areas with significant dye penetration (Rhodamine B), as seen in Figures 1 and 2 .

Efeoglu et al. (19) used computerized tomography to examine human enamel specimens that were treated for 15 days ( $8 \mathrm{~h}$ daily) with $10 \% \mathrm{CP}$. The authors reported that enamel demineralization depth reached 50 $\mu \mathrm{m}$. Conversely, Bizhang et al. (20) evaluated bovine
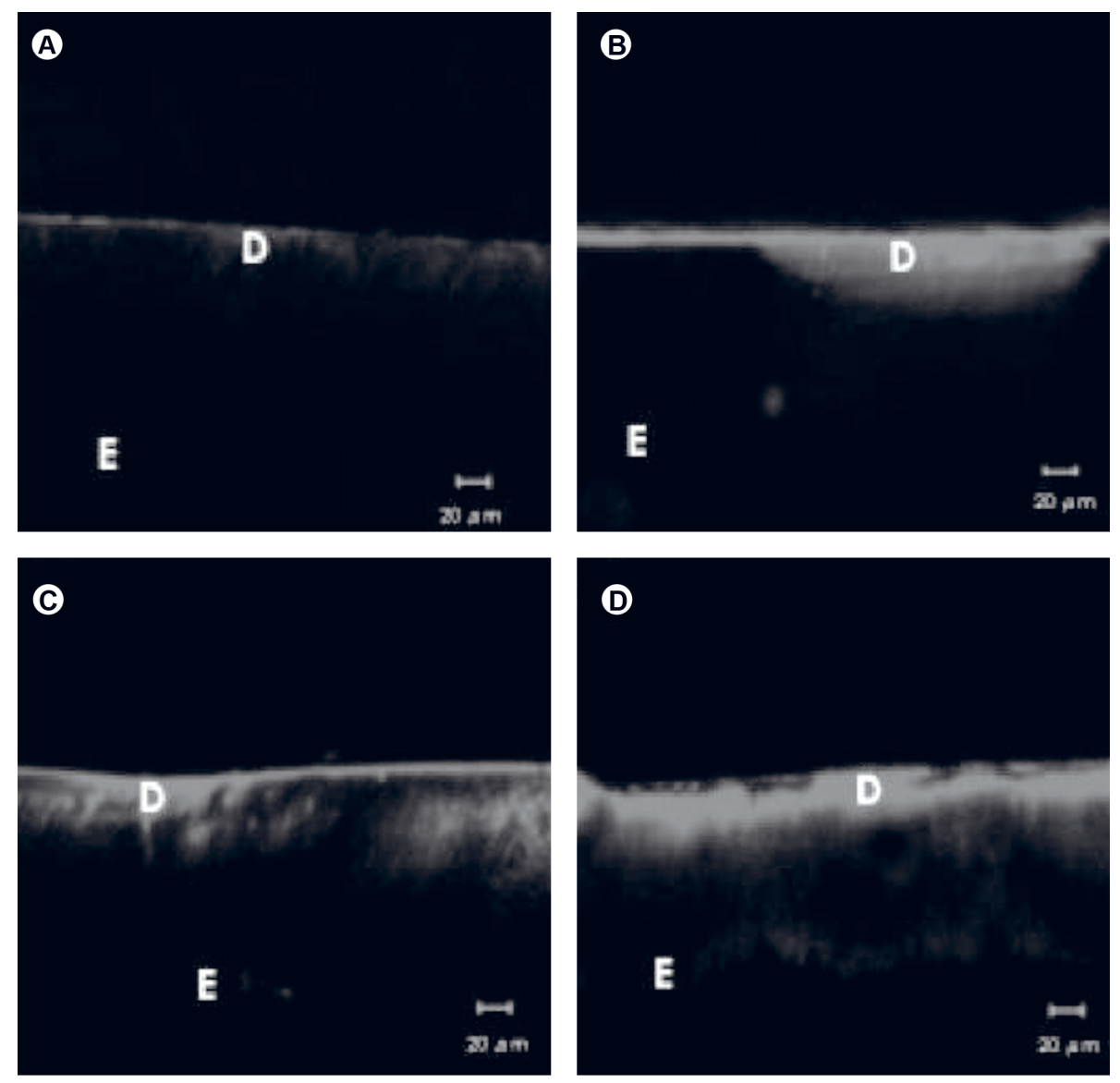

Figure 1. Confocal laser scanning microscopy images representative of sound enamel (D, demineralization; E, sound enamel). A: Control group; B: $4 \%$ hydrogen peroxide $+0.05 \% \mathrm{Ca}$; C: $4 \%$ hydrogen peroxide; $\mathrm{D}: 7.5 \%$ hydrogen peroxide $+\mathrm{ACP}$. 
enamel after treatments with $10 \% \mathrm{CP}(8 \mathrm{~h}$ daily for 2 weeks) or 5.3\% HP ( $1 \mathrm{~h}$ daily for 2 weeks) and found lesion depths of $4.8 \mu \mathrm{m}$ and $1.6 \mu \mathrm{m}$, respectively. Attin et al. (21) showed that the reduction in hardness of enamel was confined to superficial layers, confirming the demineralization in depth. In this current study the demineralization depth caused by $\mathrm{pH}$ cycling was $135 \mu \mathrm{m}$, which corresponded to the control group (unbleached). The bleaching treatments did not increase the demineralization depth for the $\mathrm{pH}$-cycled groups that ranged from $166(4 \% \mathrm{HP}+0.05 \% \mathrm{Ca}$ or $4 \% \mathrm{HP})$ to 168 $\mu \mathrm{m}(7.5 \% \mathrm{HP}+\mathrm{ACP})$. The whitening treatment of sound bleached, resulted in a demineralization depth, which ranged from $31(4 \% \mathrm{HP})$ to $52 \mu \mathrm{m}(7.5 \% \mathrm{HP}+\mathrm{ACP})$.

$\mathrm{pH}$ cycling was used because it simulates the dynamic process of caries lesion development, alternating demineralization and remineralization periods (10). The role of $\mathrm{Ca}$ and phosphate ions in demineralization and remineralization process is clearly established, but the influence of organic content of saliva should also be considered. This is a limitation of an in vitro study that cannot reproduce all variables acting in in situ or in vivo studies.

Increase of dye penetration was more intense for the enamel with artificial caries lesions (Fig. 2) than sound bleached enamel due to the mineral loss induced by $\mathrm{pH}$ cycling. Figures $2 \mathrm{~B}$ and $2 \mathrm{D}$ are representatives CSLM images of groups submitted to bleaching agents containing $\mathrm{Ca}$ ions and $\mathrm{ACP}$, respectively. Their demineralization fluorescence areas were similar to that observed for 4\% HP (Fig. 2C) and control group (Fig. 2A). Thus, the induction of artificial caries lesions for $\mathrm{pH}$ cycling was the determinant factor for dye penetration and not the bleaching treatments. Furthermore, the bleaching composition had no influence on demineralization of sound enamel or enamel with early artificial lesions.

The bleaching treatments promoted increased sound enamel demineralization, while the addition of $\mathrm{Ca}$ ions or ACP did not prevent/reverse the effects caused
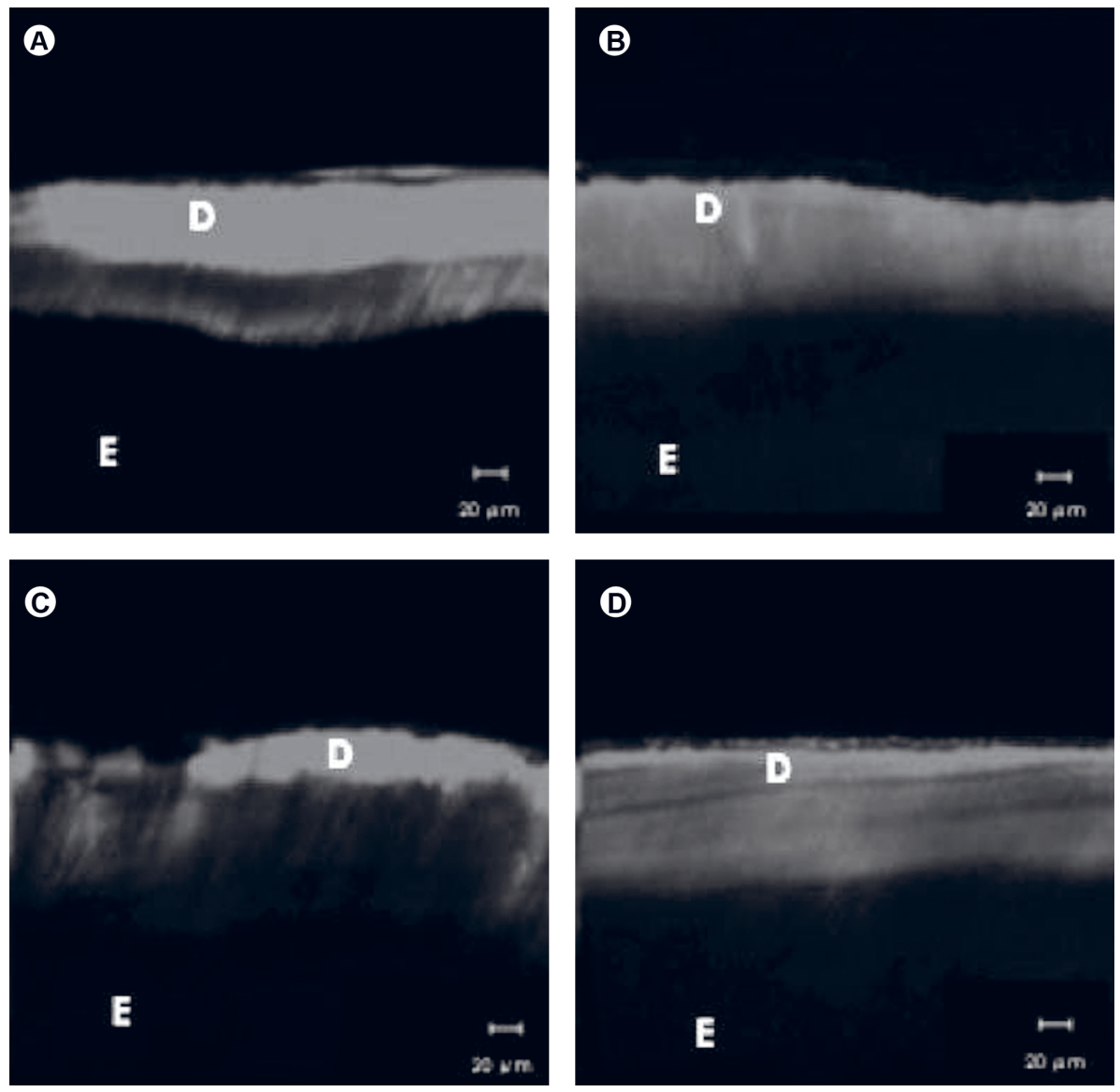

Figure 2. Confocal laser scanning microscopy images representative of early artificial caries lesions enamel (D, demineralization; E, sound enamel). A: Control group; B: 4\% hydrogen peroxide $+0.05 \% \mathrm{Ca}$; $: 4 \%$ hydrogen peroxide; D: $7.5 \%$ hydrogen peroxide + ACP. 
by the bleaching treatment in both conditions of the enamel. Early artificial caries induced by $\mathrm{pH}$ cycling model were not affected by the bleaching treatment, regardless of the type of bleaching agent.

\section{RESUMO}

O objetivo deste estudo foi avaliar o efeito de agentes clareadores no esmalte sadio (ES) ou esmalte com lesão inicial de cárie artificial (LC), utilizando microscopia confocal laser de varredura (CLSM). Oitenta blocos ( 4 × 5 x $5 \mathrm{~mm}$ ) de esmalte bovino foram usados, sendo que 40 destes foram desmineralizados com ciclagem de $\mathrm{pH}$ para induzir a LC. Oito grupos experimentais foram obtidos a partir dos tratamentos e condição do esmalte (ES ou LC), com n=10: Grupos ES: G1 - sem tratamento (controle); G2 - peróxido de hidrogênio 4\% (PH4); G3: PH4 contendo $0,05 \%$ cálcio (Ca); G4 - peróxido de hidrogênio 7,5\% (pH 7,5) contendo fosfato de cálcio amorfo (ACP). Grupos LC: G5 - não clareado; G6 - pH 4; G7 - pH 4 Ca; G8 - pH 7,5 ACP. Os grupos G2, G3, G6 e G7 foram tratados com o gel clareador por $8 \mathrm{~h} /$ dia durante 14 dias, enquanto as amostras dos grupos G4 e G8 foram submetidas ao agente clareador por $30 \mathrm{~min} /$ duas vezes ao dia, durante 14 dias. Os blocos de esmalte foram corados com solução de Rodamina B e a área fluorescente de desmineralização foi quantificada utilizando CLSM. Os dados foram submetidos a ANOVA e teste de Fisher $(\mathrm{p}<0,05)$. Para ES, os tratamentos clareadores aumentaram significativamente a área de desmineralização quando comparado com os grupos não clareados, entretanto, para LC não foi observado diferença estatística significante entre os grupos. A adição de ACP e Ca na composição dos géis clareadores não anulou os efeitos dos tratamentos clareadores no ES, assim como não teve capacidade de remineralizar o LC.

\section{ACKNOWLEDGEMENTS}

This study was supported by grants from The São Paulo State Research Foundation - FAPESP (\#07/54784-1).

\section{REFERENCES}

1. Haywood VB, Heymann HO. Nightguard vital bleaching. Quintessence Int 1989;20:173-176.

2. Haywood VB. History, safety, and effectiveness of current bleaching techniques and applications of the nightguard vital bleaching technique. Quintessence Int 1992;23:471-488.

3. Haywood VB, Leonard RH, Nelson CF, Brunson WD Effectiveness, side effects and long-term status of nightguard vital bleaching. J Am Dent Assoc 1994;125:1219-1226.

4. Seghi RR, Denry I. Effects of external bleaching on indentation and abrasion characteristics of human enamel in vitro. J Dent Res 1992;71:1340-1344.

5. Cavalli V, Arrais CA, Giannini M, Ambrosano GM. Highconcentrated carbamide peroxide bleaching agents effects on enamel surface. J Oral Rehabil 2004;31:155-159.

6. Tschoppe P, Neumann K, Mueller J, Kielbassa AM. Effect of fluoridated bleaching gels on the remineralization of predemineralized bovine enamel in vitro. J Dent 2009;37:156-162.

7. Attin T, Betke H, Schippan F, Wiegand A. Potential of fluoridated carbamide peroxide gels to support post-bleaching enamel rehardening. J Dent 2007;35:755-759.

8. Milnar FJ. Considering biomodification and remineralization techniques as adjuncts to vital tooth-bleaching regimens. Compend Contin Educ Dent 2007;28:234-236, 238-240.

9. de Oliveira R, Paes Leme AF, Giannini M. Effect of a carbamide peroxide bleaching gel containing calcium or fluoride on human enamel surface microhardness. Braz Dent J 2005;16:103-106.

10. Pinto CF, Paes Leme AF, Cavalli V, Giannini M. Effect of $10 \%$ carbamide peroxide bleaching on sound and artificial enamel carious lesions. Braz Dent J 2009;20:48-53.

11. Gonzalez-Cabezas C, Fontana M, Dunipace AJ, Li Y, Fischer GM, Proskin HM, et al.. Measurement of enamel remineralization using microradiography and confocal microscopy. A correlational study. Caries Res 1998;32:385-392.

12. Xie $\mathrm{Q}, \mathrm{Bedran}-\mathrm{Russo} \mathrm{AK}, \mathrm{Wu} \mathrm{CD}$. In vitro remineralization effects of grape seed extract on artificial root caries. J Dent 2008;36:900906.

13. Watson TF. A confocal optical microscope study of the morphology of the tooth/restoration interface using Scotchbond 2 dentin adhesive. J Dent Res 1989;68:1124-1131.

14. Gotz H, Duschner H, White DJ, Klukowska MA. Effects of elevated hydrogen peroxide 'strip' bleaching on surface and subsurface enamel including subsurface histomorphology, micro-chemical composition and fluorescence changes. J Dent 2007;35:457-466.

15. Markovic L, Jordan RA, Lakota N, Gaengler P. Micromorphology of enamel surface after vital tooth bleaching. J Endod 2007;33:607610.

16. Pinto CF, Oliveira R, Cavalli V, Giannini M. Peroxide bleaching agent effects on enamel surface microhardness, roughness and morphology. Braz Oral Res 2004;18:306-311.

17. Berger SB, Cavalli V, Ambrosano GM, Giannini M. Changes in surface morphology and mineralization level of human enamel following in-office bleaching with $35 \%$ hydrogen peroxide and light irradiation. Gen Dent 2010;58:e74-e79.

18. Abouassi T, Wolkewitz M, Hahn P. Effect of carbamide peroxide and hydrogen peroxide on enamel surface: an in vitro study. Clin Oral Investig 2011;15:673-680.

19. Efeoglu N, Wood D, Efeoglu C. Microcomputerised tomography evaluation of $10 \%$ carbamide peroxide applied to enamel. J Dent 2005;33:561-567.

20. Bizhang M, Seemann R, Duve G, Romhild G, Altenburger JM, Jahn KR, et al.. Demineralization effects of 2 bleaching procedures on enamel surfaces with and without post-treatment fluoride application. Oper Dent 2006;31:705-709.

21. Attin T, Vollmer D, Wiegand A, Attin R, Betke H. Subsurface microhardness of enamel and dentin after different external bleaching procedures. Am J Dent 2005;18:8-12.

Received January 31, 2011 Accepted December 16, 2011 